\title{
MOTIF UKIR DALAM KREASI BATIK KHAS JEPARA
}

\section{Carved Motifs In Typical Jepara Batik Creations}

\author{
Eka Amalia Wulandari ${ }^{1}$ dan Irfa'ina Rohana Salma² \\ 1Program Studi Seni Kriya, Institut Seni Indonesia Yogyakarta, J. Parangtritis 6,5 Yogyakarta, Indonesia. \\ 2Balai Besar Kerajinan dan Batik, Jl. Kusumanegara No. 7 Yogyakarta, Indonesia
}

\begin{tabular}{lll}
\hline Korenspondesi Penulis & Naskah Masuk : 17 Februari 2019 \\
Email $:$ ekazamas9411@gmail.com & Revisi & $: 15$ Mei 2019 \\
& Disetujui & $: 16$ Mei 2019 \\
\hline
\end{tabular}

Kata kunci: seni ukir kayu, motif batik, Jepara

Keywords: wood carving art, batik motif, Jepara

\begin{abstract}
ABSTRAK
Kepandaian membatik di Jepara sudah ada sejak zaman R.A. Kartini (1879-1904), tetapi tidak berkembang sebagaimana industri kreatif lainnya seperti ukir kayu, perhiasan monel, ataupun kain tenun Troso. Dewasa ini kegiatan industri batik di Jepara mulai tumbuh dan berkembang kembali. IKM melakukan penciptaan motif khas daerah dengan mengambil inspirasi dari motif seni ukir kayu, namun hasilnya masih terlihat kaku atau kurang sesuai untuk motif hias pada kain sandang. Tujuan penciptaan seni ini adalah sebagai ikhtiar sumbangsih untuk menghasilkan motif batik yang lebih serasi, terinspirasi dan dikembangkan dari seni ukir kayu Jepara. Metode yang digunakan yaitu pengumpulan data, pengkajian sumber inspirasi, perwujudan menjadi kain batik, dan penilaian estetika motif. Kegiatan ini menghasilkan 10 motif yaitu Lung Merak, Lung Ngrembaka, Lung Cinta Jepara, Lung Wuni, Lung Gunung, Lung Lereng, Ceplok Semi, Ceplok Poleng, Ceplok Ukir, dan Ceplok Bal. Motif yang mendapat penilaian baik sekali (A) adalah motif Lung Merak, Ceplok Ukir, dan Ceplok Bal.
\end{abstract}

\begin{abstract}
Batik proccess know-how in Jepara already existed during the R.A Kartini (1879-1904) era, but it does not thrive as other creative industries such as wood carving, monel jewelry, and Troso weaving. Today the batik industry activities in Jepara are starting to grow and develop again. SMS's create regional motifs by taking inspiration from wood carving motifs, but as the results still look stiff or not suitable for decorative motifs on batik cloth. The purpose of this art creation is as an effort to contribute more flexible batik motifs whose inspiration developed from Jepara wood carving. The method used is data collection, source of inspiration, embodiment into batik cloth,and aesthetic assessment of motifs. This activity produced 10 motifs namely Lung Merak, Lung Ngrembaka, Lung Cinta Jepara, Lung Wuni, Lung Gunung, Lung Lereng, Ceplok Semi, Ceplok Poleng, Ceplok Ukir, and Ceplok Bal. The motifs received a very good evaluation ( $A$ ) were Lung Merak, Ceplok Ukir, and Ceplok Bal.
\end{abstract}




\section{PENDAHULUAN}

Menyebut nama Jepara maka orang akan langsung teringat seni ukir kayunya yang indah pada berbagai perabot mebel, arsitektur, dan aneka produk aksesoris interior lainnya. Jepara memang termasyur karena kepandaian seni ukir, bahkan sampai ke mancanegara. Jepara adalah sebuah kota kabupaten yang terletak di kawasan pantai utara Jawa Tengah. Jepara dikenal sebagai pusat industri mebel ukir di Indonesia (Pratiwi, Kenang, \& Ruki, 2017). Kabupaten Jepara berada dilereng barat dan lereng utara Gunung Muria. Sebelah barat dan utara Jepara berbatasan dengan Laut Jawa, sebelah timur Jepara berbatasan dengan Kabupaten Kudus dan Pati, dan sebelah selatan Jepara berbatasan dengan Kabupaten Demak (Cemerlang, 2018).

Produk kayu yang dihasilkan dari Jepara antara lain berupa: mebel, aksesoris arsitektur, aksesoris interior, relief, patung, dan sebagainya. Keunggulan produk kayu Jepara terutama pada seni ukir dan teknik pertukangan yang halus (Eskak, 2013). Kemahsyuran itu bukanlah hasil instan, tetapi telah dirintis dan senantiasa diperjuangkan secara estafet dari generasi ke generasi. Salah satu tokoh yang ikut merintis pengembangan industri seni ukir kayu dan juga memperkenalkannya ke luar negeri adalah R.A. Kartini. Pada waktu itu Kartini muda memberi semangat kepada para pengukir untuk senantiasa berkarya sekaligus berikhtiar memperkenalkan karya seni ukir Jepara ke Semarang, Batavia bahkan ke Belanda, yang di kemudian hari ditindaklanjuti dengan pengiriman karya ukiran kayu ke luar negeri untuk dipamerkan dan ternyata mendapat apresiasi yang tinggi (Sutrisno, 1985). Apresiasi dan perhatian para pecinta seni di luar negeri (Belanda) tersebut semakin memperteguh bahwa bangsa Indonesia merupakan bangsa yang mempunyai talenta tinggi pada bidang kepandaian seni (Salma, Eskak, \& Wibowo, 2016). Sutrisno (1985) menyatakan bahwa: karya-karya perajin Jepara yang dipamerkan itu ternyata telah memancing minat dan perhatian para pecinta seni di Eropa Barat. Sutarya (2014) menjelaskan bahwa R.A. Kartini telah mengekspor mebel ukir, batik, drijin (tenun), gerabah, hiasan kerang, dan barang-barang kerajinan lain ke negeri Belanda.

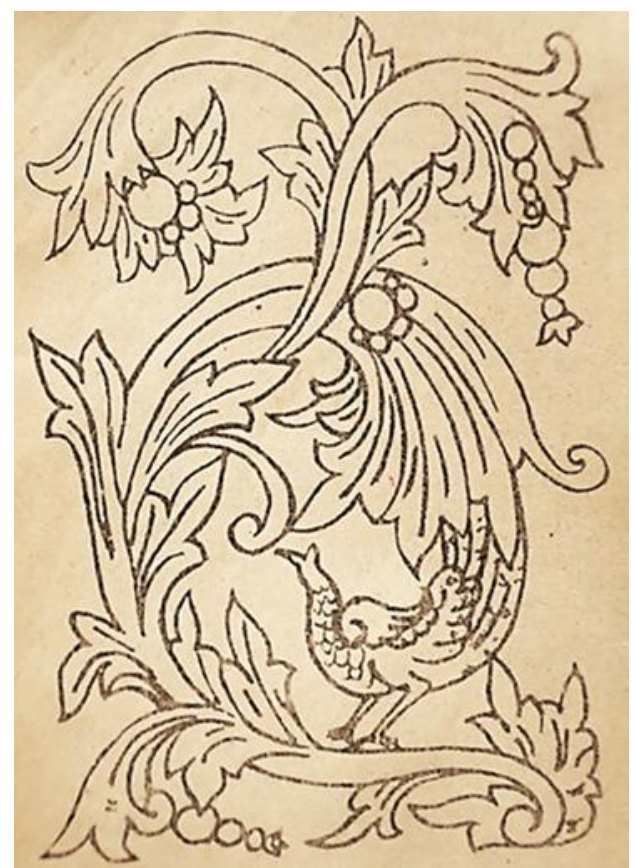

Gambar 1. Motif Ukir Merak (Sumber: Soepratno, 2004)

R.A. Kartini juga memberi perhatian yang sama terhadap kepandaian membatik di Jepara. Pahlawan Nasional ini mengajarkan keterampilan membatik 
kepada kaum wanita di pendopo kediamannya (Supriono, 2016), namun sayangnya seni batik tidak berkembang maju sebagaimana seni ukir kayu yang kini sudah menjadi industri unggulan di Jepara. Karena kesadaran sejarah, pendidikan yang mulai maju, pembinaan dari pemerintah dan para pemangku kepentingan, serta jiwa kewirausahaan anak muda, kini kegiatan industri batik di Jepara mulai bergeliat tumbuh dan berkembang kembali.

Dewasa ini pasaran batik di Jepara masih di dominasi oleh batik Solo, batik Pekalongan dan batik Lasem. Motif-motif tersebut akhirnya juga mempengaruhi corak batik yang berkembang di Jepara. Menyadari hal tersebut para budayawan dan seniman Jepara mulai gelisah dengan kondisi tersebut, solusi yang mengemuka adalah perlu menciptakan motif batik yang mempunyai ciri khas seni budaya Jepara.

\section{Seni Ukir Kayu Jepara}

Pada masa lalu kepandaian mengukir di lingkungan Keraton-Keraton Jawa dan di Kadipaten-Kadipaten daerah tertentu telah menghasilkan berbagai seni ukir yang mempunyai corak yang berbeda-beda sehingga dikenal ada motif ukir Majapahit, Pajajaran, Mataram, Cirebon, Yogyakarta, Surakarta, Semarangan, Pekalongan, dan Jepara. Motif adalah pangkal tolak atau esensi dari suatu pola hias (Gustami, 2008). Motif merupakan unsur pokok sebuah ornamen. Melalui motif, tema atau ide dasar sebuah ornamen dapat dikenali, sebab perwujudan motif umumnya merupakan gubahan atas bentuk-bentuk di alam atau sebagai representasi alam yang kasatmata
(Soepratno, 2004). Dalidjo dan Mulyadi dalam Ningrum (2015) menjelaskan bahwa ornamen ukir corak Jepara penggambaran motifnya berupa tumbuhan-tumbuhan yang dirangkai dengan motif hewan. Bentuknya menjalar yang berbatang dan beranting halus ramping. Gerak tumbuhnya melingkar-lingkar secara gemulai. Batang beruas yang ditumbuhi trubusan atau tangkai bergelung yang berakhir dengan bunga atau daun. Daunnya tergolong jenis bertulang jari dengan pecahan pada setiap jarinya dan masing-masing berujung runcing. Sebagian juga berbentuk ulir. Secara keseluruhan ornamen bercorak motif ukir Jepara tampak ramping, ringan dan lemah gemulai. Motif ukir tradisional Jepara merupakan stilasi atau penggayaan dari bentuk tumbuhan menjalar. Stilasi adalah penggubahan bentuk yang tergayakan dan umumnya bercorak hias (Sunaryo, 2018). Bentuk khas yang terdapat pada tumbuhan menjalar yaitu tangkainya kecil memanjang, daunnya lebar dan ujung daunnya lancip. Bentuk-bentuk tersebut distilasi menjadi motif ukir Jepara, sehingga secara visual ciri khas motif ukir tradisional Jepara adalah: (1) Tangkai, (lung/lunglungan) menjuntai tumbuh mengulir ritmis memenuhi bidang motif. (2) Daun, berbentuk rumbaian terbuka berujung lancip pada ujung rumbaian, umumnya berjumlah ganjil yaitu tiga, lima, dan tujuh daun berjajar rapat. (3) Buah, pada tengah pangkal daun rumbai biasanya keluar tiga, lima, atau tujuh buah bulat kecil, biasanya disebut buah wuni. (3) Semaian/trubusan, alur tumbuh unsur motif yang keluar dari sepanjang ruas tangkai atau cabang berupa daun dan buah susun 
(buah wuni yang berjajar memanjang. (4) Binatang, biasanya dipadu dengan motif wayang dan binatang (Eskak, 2018).

Motif ukir Jepara mempunyai makna memperindah hidup dengan keindahan, karena keindahan merupakan keterpaduan, keseimbangan, dan keselarasan di dalam lingkungan hidup bermasyarakat. Kebaikan dan keindahan tersebut harus ditumbuhkan agar menyebar ke segala tempat, atau motifnya ngrembaka tumbuh menyebar memenuhi bidang yang ada (Eskak, 2018). Nenek moyang bangsa Indonesia banyak mewariskan nilai luhur tentang bagaimana kearifan hidup bermasyarakat, berbangsa, dan bernegara (Eskak \& Salma, 2018). Secara visual motif ukir Jepara tersebut dapat dilihat pada Gambar 1 dan 2.

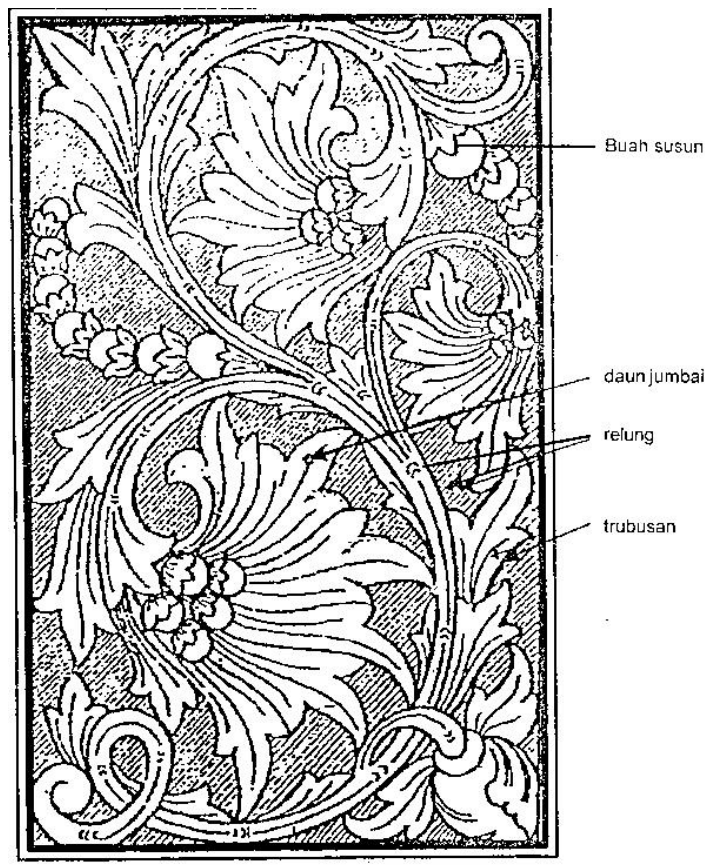

Gambar 2. Motif Ukir Wuni

(Sumber: Soepratno, 2004)

Ukiran indah pada kayu adalah karya seni. Seni adalah kemampuan istimewa dalam mengubah suatu ide menjadi konsep kreatif yang dinyatakan menjadi suatu yang menarik, fungsional, atau inspiratif (Marianto, 2017). Seni ukir adalah seni pahat. Mengukir adalah memahat, menoreh, menggores, yang dilakukan pada berbagai media dengan alat tajam. Seni ukir atau ukiran merupakan gambar hiasan dengan bagian-bagian cekung (kruwikan) dan bagian-bagian cembung (buledan) yang menyusun suatu gambar yang indah. Pengertian ini berkembang hingga dikenal sebagai seni ukir yang merupakan seni membentuk gambar pada kayu, batu, atau bahan-bahan lain (Sunaryo, 2009). Industri ukir kayu Jepara telah menjadi salah satu penggerak perekonomian daerah yang mampu meningkatan kesejahteraan masyarakat di Jepara (Eskak, 2013a).

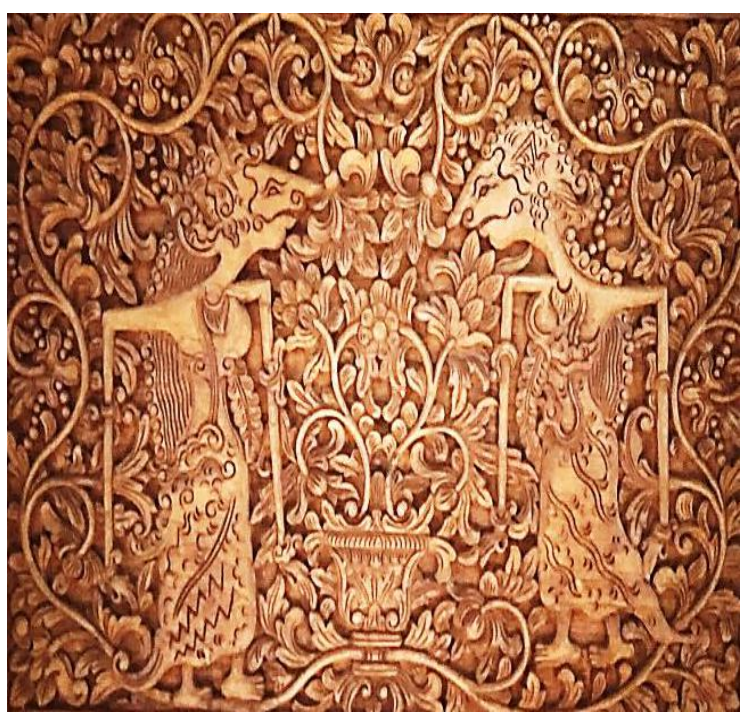

Gambar 3. Detail ukiran dari produk kotak perhiasan (Koleksi: Rumah Kartini, 2018)

Seni ukir merupakan kekayaaan budaya tradisional yang di era industri kreatif dewasa ini dapat dijadikan sumber inspirasi penciptaan seni kreatif dan inovatif sesuai 
dinamika zaman (Yoga \& Eskak, 2015). Berkaitan dalam hal ini adalah mengambil inspirasi seni ukir kayu untuk dijadikan motif batik khas Jepara. Contoh produk ukiran khas Jepara pada zaman R. A. Kartini berupa kotak perhiasan tahun 1902 yang dikirim ke perusahaan Oots en west Belanda (Kotak Perhiasan Ukir Kayu Jati Kartini Jepara, 2018). Detail motif ukirnya dapat dilihat pada Gambar 3. Produk tersebut merupakan replika yang telah dibuat oleh Komunitas Rumah Kartini Jepara. Contoh lain maha karya seni ukir Jepara adalah Gebjok Kudus. Gebjok Kudus merupakan dinding-dinding berukir yang dibuat oleh para pengukir pada rumah tradisional dengan jalinan konstruksi yang rumit dan kuat. Dinding tersebut dibuat berlubang tembus pandang atau yang sering dikenal dengan istilah krawangan. Hal itu dilakukan supaya tampilannya menjadi lebih indah dan lebih memiliki nilai estetika (Gustami, 2000). Penggubahan motif ukir menjadi motif batik dapat menghasilkan keunikan tersendiri, keunikan suatu karya seni akan mampu menarik banyak orang untuk mengoleksinya (Sukaya, Eskak, \& Salma, 2018), atau keunikan dapat meningkatkan daya jualnya. Dengan demikian penciptaan motif batik khas Jepara akan meningkatkan daya jual produk batiknya.

\section{Seni Batik Jepara}

Kepandaian membatik sebagai ketrampilan membuat sandang sudah ada di Jepara ketika zaman R.A. Kartini yaitu antara tahun 1879 hingga tahun 1904. Rouffaer dalam Supriono (2016) menjelaskan bahwa R.A. Kartini pernah mengirim cinderamata kepada sahabatnya di negeri Belanda berupa kain batik khas Jepara dan tenun ikat Troso. Motif batik Jepara pada mulanya yang terkenal motif Bunga Kantil, Parang Gondosuli, dan Srikaton yang bergaya Mataraman, namun berbeda dengan yang berkembang di Solo dan Yogyakarta.

Batik yang kini mulai berkembang lagi di Jepara adalah batik asli, yaitu menggunakan lilin panas sebagai bahan perintang warna yang prosesnya melalui tahapan-tahapan yang spesifik. Batik dibuat secara spesifik yaitu dengan penggunaan lilin batik sebagai bahan perintang dalam proses pewarnaannya (Salma, Wibowo, \& Satria, 2015). Teknik membatik merupakan proses-proses pekerjaan dari permulaan penyiapan mori sampai menjadi kain batik (Susanto, 2018). Lilin batik atau malam berfungsi merintangi resapan warna dalam pencelupan, sehingga terjadilah kontras warna antara kain yang ditutup lilin (menolak warna) dengan kain yang terbuka sehingga terwarnai. Proses pembuatan batik motif khas Jepara mengacu SNI 0239:2014. SNI (Standar Nasional Indonesia) tersebut tentang: Batik - Pengertian dan Istilah, yaitu batik adalah kerajinan tangan sebagai hasil pewarnaan secara perintangan menggunakan malam (lilin batik) panas sebagai perintang warna dengan alat utama pelekat lilin batik berupa canting tulis dan atau canting cap untuk membentuk motif tertentu yang memiliki makna. Batik tulis adalah batik yang dibuat dengan menggunakan alat utama canting tulis sebagai alat melekatkan malam (BSN, 2014). 


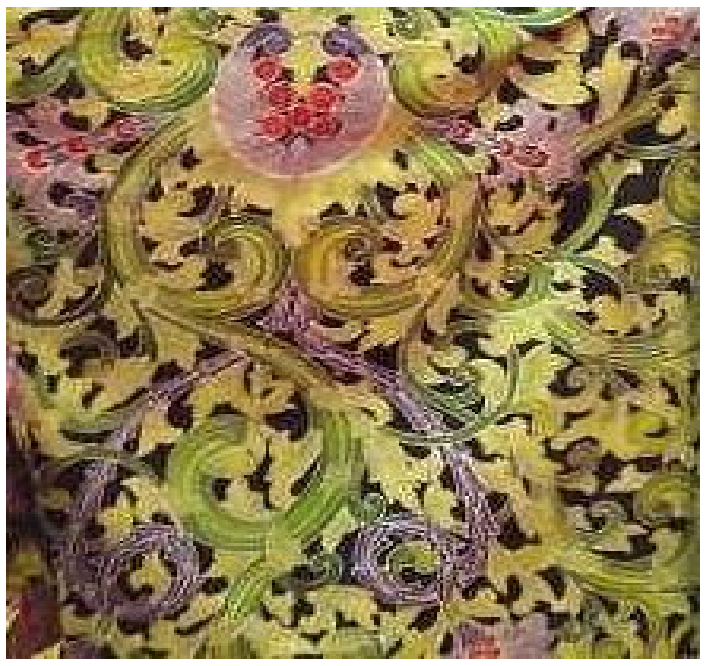

Gambar 4. Batik Motif Ukir Jepara (Indriani \& Rachmawati, 2016)

IKM batik Jepara ada yang sudah berkreasi menerapkan motif ukir ke dalam motif batik, namun karya motifnya masih terasa "kaku" sebagai motif kayu, belum "luwes" sebagaimana lazimnya motif untuk kain. Contohnya dapat dilihat dalam Gambar 4. Oleh karena itu penulis merasa tertantang untuk melakukan penciptaan motif ukir pada kain yang secara visual lebih luwes. Pengalihan dari motif ukir yang lazimnya pada papan kayu yang keras ke bahan kain sandang yang lembut tentunya memerlukan penyesuaian-penyesuaian bentuk dari unsur-unsur motif tersebut. Motif seni ukir khas Jepara merupakan motif hasil stilasi dari tumbuh-tumbuhan berupa bunga, daun, batang sulur (lung), dan binatang. Pertimbangan-pertimbangan tersebut akan dijadikan acuan dalam penciptaan motif-motif baru agar motif ukir menjadi tampak luwes. Arah pengembangan motifnya adalah batik corak pesisiran yaitu batik yang berkembang di luar batas-batas dinding keraton, khususnya di daerah pesisir utara Jawa.
Sifatnya beraneka ragam setiap sentra batik menghasilkan corak-corak yang amat bervariasi warnanya tak terbatas pada warna coklat dan biru melainkan juga menampilkan warna merah, hijau, biru muda, dan kuning (Sutarya, 2014).

Tujuan penciptaan seni ini adalah ikhtiar sumbangsih untuk menghasilkan motif batik khas Jepara yang inspirasinya dikembangkan dari seni ukir kayu Jepara. Kejayaan yang telah dicapai oleh industri seni ukir kayunya, diharapkan juga dapat diikuti oleh industri batiknya pada masa yang akan datang.

\section{METODOLOGI PENELITIAN}

Metode yang digunakan yaitu pengumpulan data, analisis data, pembuatan desain motif, dan perwujudan menjadi kain batik. Data tentang seni ukir Jepara diperoleh dari studi pustaka dan observasi. Studi pustaka dilakukan dengan membaca referensi yang relevan. Observasi adalah pengamatan, namun pengamatan yang dilakukan secara cermat dan mendalam terhadap suatu objek atau permasalahan (Eskak, 2014). Data yang diperoleh berupa data tertulis dan data gambar. Berdasarkan data yang diperoleh, kemudian dilakukan analisis untuk memperoleh gagasan atau ide penciptaan. Ide masih berupa abstraksi pikiran, maka perlu divisualkan dalam bentuk sketsa di kertas. Sketsa merupakan visualisasi awal dari imajinasi tentang suatu karya seni yang ingin diwujudkan (Eskak, 2013b). Dari sketsa-sketsa yang dihasilkan, kemudian dipilih yang terbaik untuk diproses menjadi desain motif. Desain motif kemudian dibuat 
gambar kerja skala 1:1 untuk diblat atau dipindahkan pada kain putih. Proses selanjutnya adalah proses pembatikan menjadi kain batik khas Jepara.

\section{Bahan dan Alat}

Bahan dan alat yang digunakan dapat dipilah menjadi dua bagian yaitu bahan untuk membuat desain dan bahan untuk membuat batik. Bahan dan alat pembuatan desain adalah kertas gambar, pensil, karet penghapus, spidol hitam, penggaris, dan drawing pen 0.3 hitam. Bahan dan alat untuk pembuatan batiknya adalah adalah kain katun, lilin batik, zat warna naphtol dan bahan peramunya (caustic soda dan TRO) serta garam pembakitnya (Red B, RedR, Orange GC, Black $B$, Blue $B$ ), zat warna indigosol (Blue O4B, Rose IR, Orange $H R$, Yellow IGK, Green IB, Brown IRRD) dan bahan pembakitnya (Nitrite / Na No2) serta bahan penguncinya ( $\mathrm{HCl}$ ditambah air), zat warna rapid (merah), dan air tawar bersih.

Peralatan pembuatan batiknya adalah canting tulis, kompor batik, timbangan zat warna, cawan pengaduk warna, bak pewarna, peralatan pelorodan, penjemuran teduh, dan setrika. Urutan proses pembatikannya seperti pembuatan kain batik pada umumnya yaitu pelekatan lilin, pewarnaan, dan pelorodan atau pelepasan lilin. Dilakukan pula variasi pewarnaan dan penutupan lilin, sehingga menghasilkan motif dengan warna-warni yang lebih beragam dan menarik.

\section{Prosedur Kerja \\ Metode yang digunakan dalam penciptaan seni ini adalah dengan}

mengumpulkan data dari lapangan serta dilengkapi data dari jurnal, buku, dan internet. Data juga didapatkan dengan metode wawancara. Wawancara kepada kepada narasumber yang ahli di bidang seni ukir. Data yang telah dikumpulkan, kemudian dianalisis sebagai panduan berkarya menciptakan motif batik khas Jepara. Hasil analisis berupa penentuan tema penciptaan. Langkah selanjutnya adalah dilakukan pembuatan sketsa-sketsa. Sketsa merupakan goresan tinta di atas kertas sebagai visualisasi awal dari ide motif yang akan diciptakan. Hasil sketsa yang bagus akan dipilih untuk disempurnakan lagi menjadi desain motif. Desain motif kemudian diperbesar menjadi gambar kerja dengan skala 1:1 untuk dipindahkan pada bahan kain untuk dikerjakan dalam proses pembatikan menjadi kain batik khas Jepara. Selanjutnya dilakukan penilaian estetika motif oleh ahli batik. Bagan metode penciptaan ditampilkan dalam Gambar 5.

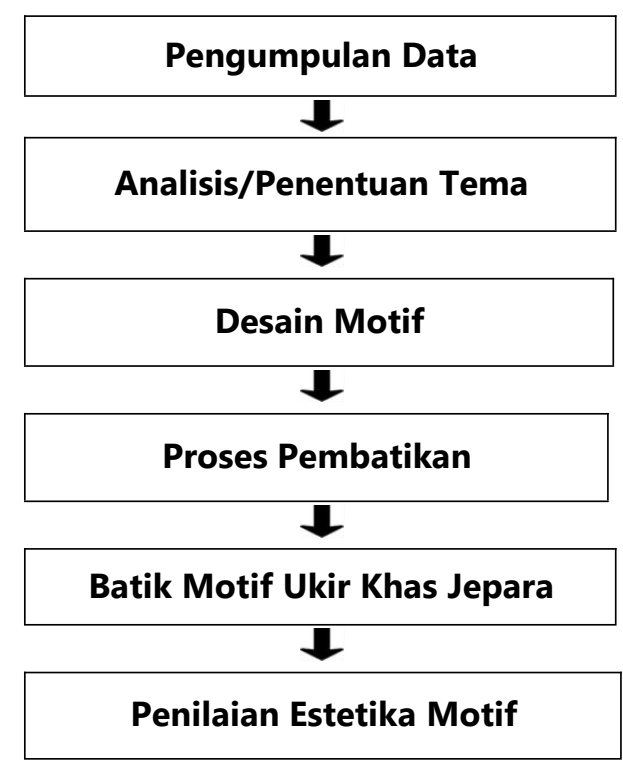

Gambar 5. Bagan metode penciptaan batik khas Jepara 


\section{HASIL DAN PEMBAHASAN}

Hasil

Kegiatan ini menghasilkan 10 batik khas Jepara yaitu motif: Lung Merak, Lung Ngrembaka, Lung Cinta Jepara, Lung Wuni, Lung Gunung, Lung Lereng, Ceplok Semi, Ceplok Poleng Ceplok Ukir, dan Ceplok Bal.

\section{Pembahasan}

\section{Motif Lung Merak}

Motif ini merupakan penggabungan motif ukir (Gambar 1 dan 2) ) menjadi motif batik dengan judul Lung Merak (Gambar 6). Motifnya berupa rangkaian lung, daun, bunga, buah, dan burung merak. Pada selasela komposisi motif pokok diberi motif isian berupa titik-titik (cecek). Hal ini dilakukan untuk memperhalus motif ukir yang cenderung kaku menjadi terlihat lebih lembut (Salma \& Eskak, 2016). Motif ini menggambarkan keindahan flora dan fauna klangenan dari bangsawan masa lampau, menyimbolkan keindahan, kemapanan, dan kesejahteraan hidup.

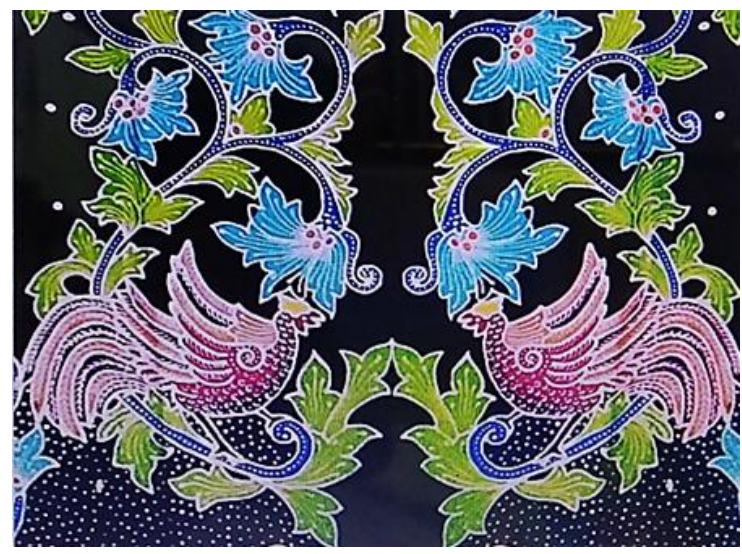

Gambar 6. Motif Lung Merak

\section{Motif Lung Ngrembaka}

Motif ini pengembangan dari motif ukir (Gambar 2) menjadi motif batik dengan judul Lung Ngrembaka (Gambar 7). Motifnya berupa rangkaian lung/sulur, daun, bunga, dan buah. Ngrembaka adalah bahasa Jawa yang artinya tumbuh bersemi dan berkembang menjadi lebat.

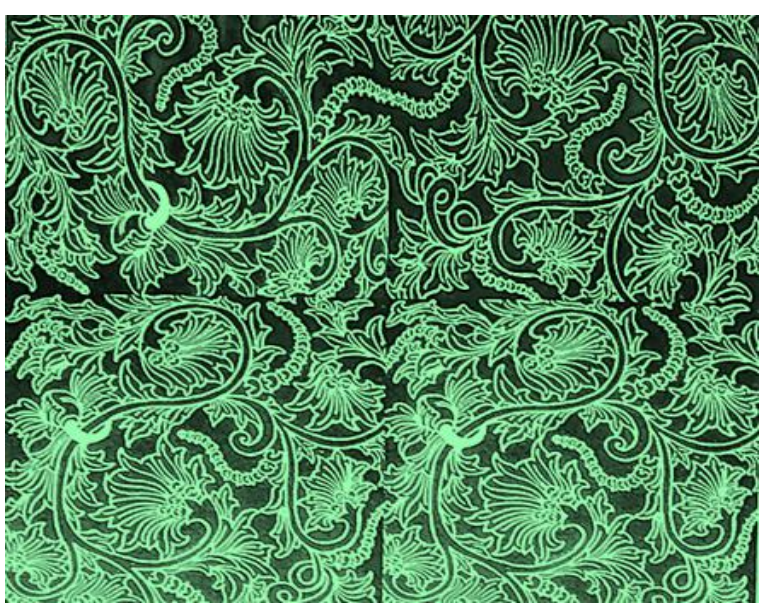

Gambar 7. Motif Lung Ngrembaka

Motif ini menggambarkan keindahan dan kebaikan yang tumbuh menjalar ke segala arah. Warna hijau pada motif melambangkan kesuburan. Motif ini juga menggambarkan budaya merantau sebagian warga Jepara dengan berbekal keahlian tukang kayu dan pengukir yang datang ke berbagai kota dan daerah untuk mencari nafkah. Budaya merantau tersebut laksana menjalarkan keindahan/kebaikan ke berbagai tempat baru, karena hasil pekerjaannya berupa mebel dan ukiran yang indah. Keahlian tukang kayu dan pengukir alusan dari Jepara (Eskak, 2013a) turut menyebarkan kebaikan dan keindahan lewat karya mebel dan seni ukirnya.

\section{Motif Lung Cinta Jepara}

Motif batik ini merupakan pengembangan motif ukir yang sulurnya digubah membentuk hati, yang 


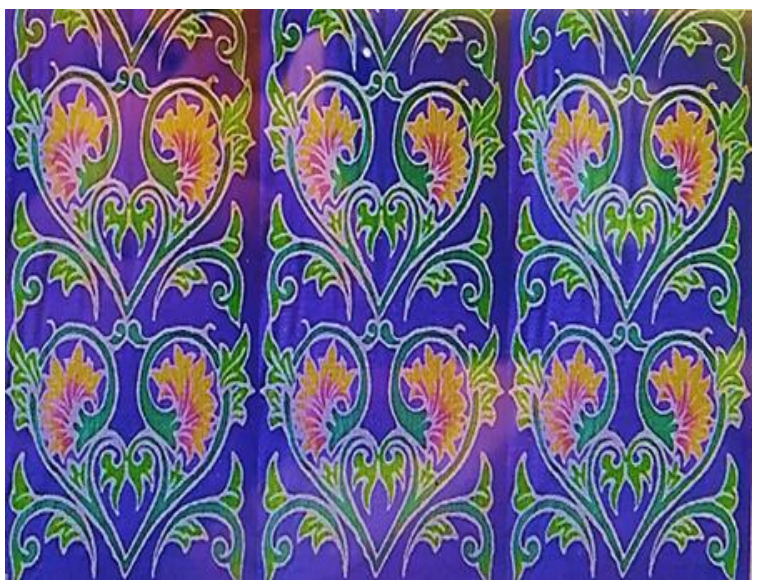

Gambar 8. Motif Cinta Jepara

melambangkan cinta, sedangkan identitas Jepara adalah motif ukirnya, sehingga motif yang dihasilkan diberi judul Lung Cinta Jepara (Gambar 8). Sulur-sulur atau lung yang tumbuh berkembang menyebar menyimbolkan bahwa cinta kasih terhadap sesama manusia dan cinta daerah/nasional dapat disemai dan dirawat oleh warga Jepara di manapun berada. Rasa solidaritas dan nasionalisme yang dirintis dari ekspresi seni-seni daerah (Eskak \& Salma, 2018).

\section{Motif Lung Wuni}

Motif ukir sebagai stilasi buah wuni merupakan salah satu ciri khas motif ukir Jepara. Wuni adalah buah bulat berukuran kecil bertangkai dalam bentuk untaian yang khas. Buah ini rasanya masam, manis, dan segar serta banyak dipakai sebagai campuran rujak bebek. Pohon buah wuni masih banyak dijumpai di Jepara (Indriani $\&$ Rachmawati, 2016). Motif ini menggambarkan keindahan dan kesegaran motif dan warna batik khas pesisir utara.

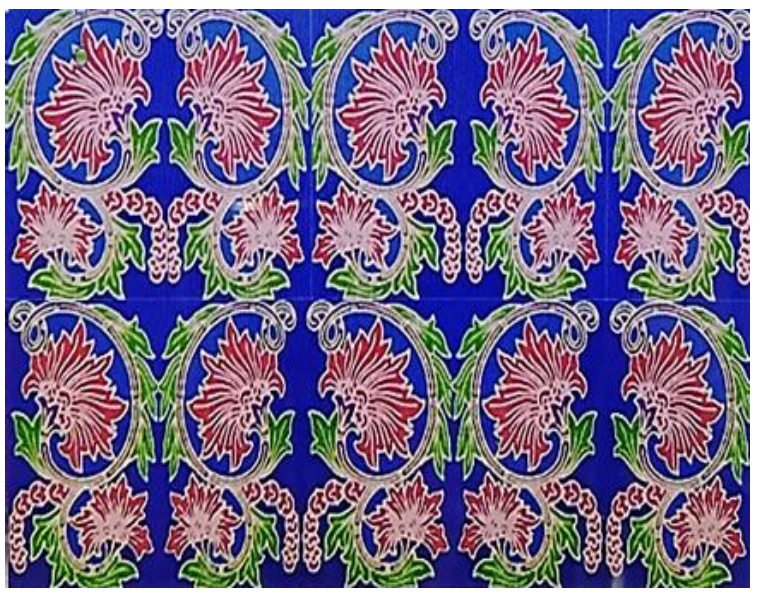

Gambar 9. Motif Lung Wuni

\section{Motif Lung Gunung}

Motif ini memadukan keunikan motif ukir dan keindahan alam pegunungan. Walaupun sebagian besar wilayah Jepara adalah pesisir, namun juga terdapat beberapa gunung kecil dan satu gunung besar yaitu Gunung Muria. Gunung menyimbolkan keagungan, kesuburan, dan misteri. Karya seni merupakan ekspresi dari simbol-simbol kepercayaan, kebudayaan, adat leluhur, cinta kasih, tuntunan kehidupan, perjuangan hidup, dan maknamakna luhur lainya (Eskak \& Sumarno, 2016). Motif ini menggambarkan anugerah

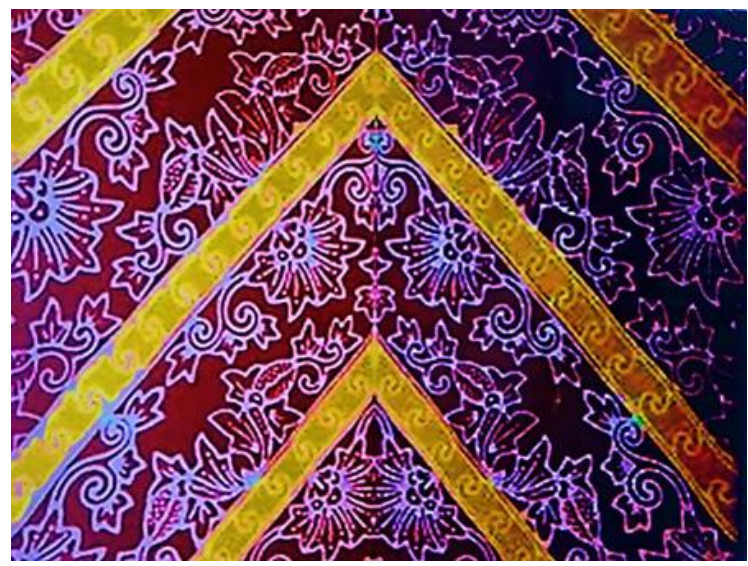

Gambar 10. Motif Lung Gunung 
keindahan dan kesuburan alam pegunungan yang mengalirkan rejeki ke berbagai wilayah di lereng-lerengnya. Bila seseorang mendapatkan berkat rejeki yang berlimpah atau memiliki rejeki yang menggunung (baik harta ataupun ilmu) hendaklah berderma seperti gunung yang mengalirkan kebaikan kepada sesama yang membutuhkan.

\section{Motif Lung Lereng}

Motif ini terinspirasi dari sulur-sulur berulir. Motif ukir yang dikreasikan dalam pola ritmis miring atau lereng sehingga motifnya diberi judul Lung Lereng (Gambar 11). Motif jenis ini dalam komposisi alur miring dalam sudut $45^{\circ}$. Makna motif ini adalah semangat pantang menyerah selalu tumbuh menjalar mengulir dalam menjalankan ikhtiar menebar keindahan dan kebaikan. Motif lereng yaitu motif yang mempunyai bentuk dasar garis-garis miring sejajar (Salma, Eskak, \& Wibowo, 2016). Halangan dan rintangan bukan menjadi kendala, tetapi justru sebaliknya dapat menjadi pemicu untuk mencapai hasil yang jauh lebih baik. Garis miring dalam kajian ilmu desain, memiliki arti garis yang bergerak atau dinamis (Sanyoto, 2010).

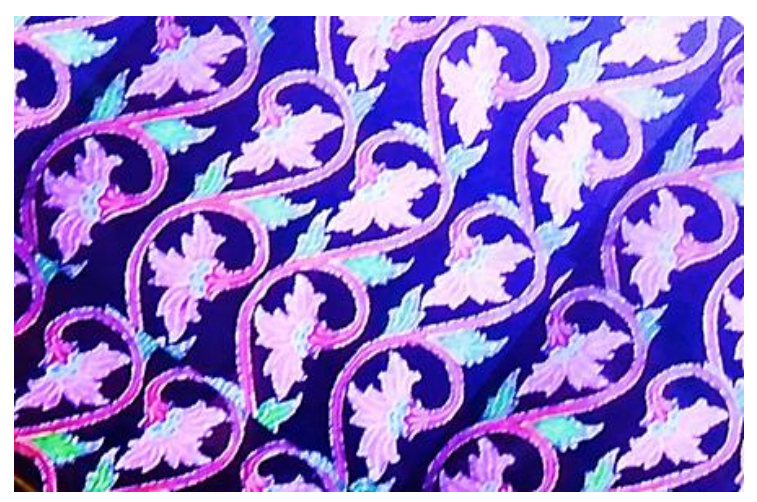

Gambar 11. Motif Lung Lereng

\section{Motif Ceplok Semi}

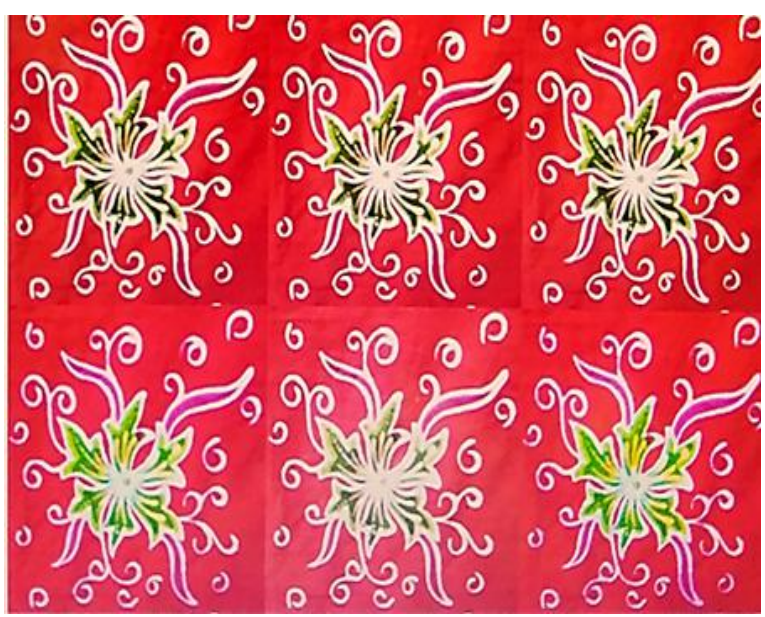

Gambar 12. Motif Ceplok Semi

Motif ini terinspirasi dari batik motif ceplok corak Solo-Jogja, yang kemudian dikreasikan dengan unsur motif ukir yaitu bentuk daun dan kuncup semaian, dengan judul Ceplok Semi (Gambar 12). Motif kreasi baru ini menggambarkan tumbuhnya kembali tunas-tunas kehidupan baru, ceplok menggambarkan bagian-bagian yang terpisah, artinya bibit-bibit mandiri yang mulai bertunas dan mekar daunnya tidak hanya satu, tetapi banyak jumlahnya. Simbolik dari harapan akan tumbuhnya kreativitas-kreativitas baru dari generasi muda (Eskak, 2013) khususnya di wilayah Jepada untuk menciptakan industi kreatif pada masa kini. Industri kreatif untuk menopang kemajuan ekonomi daerah menuju kehidupan yang lebih maju dan sejahtera. Kreativitas tersebut selain akan membuktikan bahwa seni dapat memajukan ekonomi daerah, juga merupakan upaya melestarikan seni budaya daerah. 


\section{Motif Ceplok Poleng}

Penciptaan motif ini juga terinspirasi motif batik corak Solo-Jogja, yaitu motif ceplok dan poleng. Unsur ceploknya masih menggunakan motif Ceplok Semi (Gambar 12) namun ukuran motif diperkecil dan ditata dalam kotak-kotak poleng secara teratur dan ritmis. Poleng juga dekat dengan kekhasan Bali yang bermakna ekspresi penghayatan konsep rwa bhineda, suatu konsep keseimbangan antara baik dan buruk (Salma, Masiswo, Satria, \& Wibowo, 2015). Namun dalam motif Ceplok Poleng Jepara ini dikreasikan dengan motif ukir khas Jepara, sehingga hasil karya motifnya secara visual berbeda dengan motif Poleng Bali. Makna dari motif Ceplok Poleng ini adalah keseimbangan dalam hidup, sehingga dapat menjalani kehidupan ini secara harmonis dalam diri sendiri, maupun dalam bermasyarakat, serta berkeTuhan-an, agar dapat menggapai hidup yang bahagia dan sejahtera.

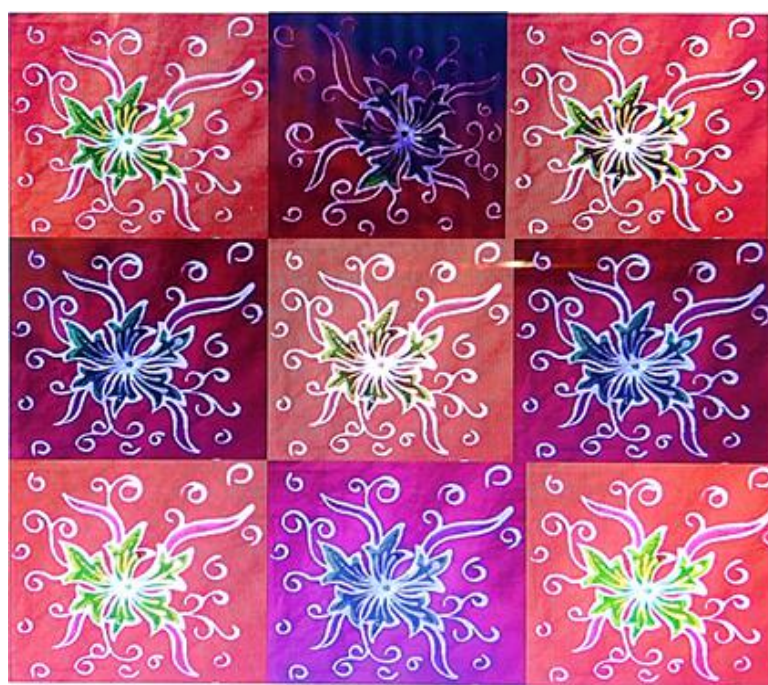

Gambar 13. Motif Ceplok Poleng

\section{Motif Ceplok Ukir}

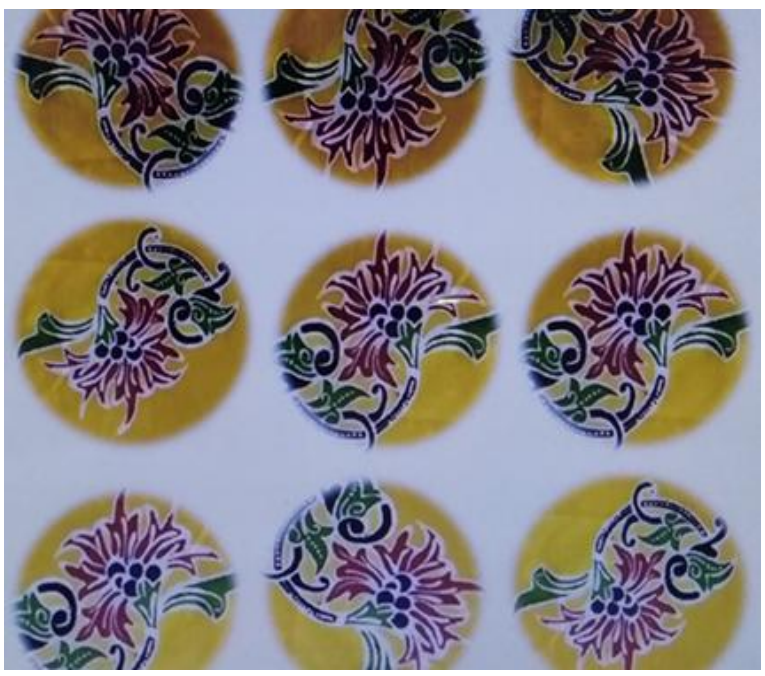

Gambar 14. Motif Ceplok Ukir

Motif baru ini mengandung 2 motif pokok yaitu motif ukir khas Jepara dalam bingkai latar bentuk bulat/lingkaran. Bentuk bulat tersebut melambangkan bola, yaitu simbolik masyarakat Jepara (baik laki-laki maupun perempuan) yang begitu gandrung mendukung klub sepak bola asal daerah yang telah beberapa kali berprestasi pada tingkat nasional. Kecintaan tersebut juga telah diekspresikan pada varian salah satu produk ukiran khas Jepara lainnya, yaitu seni ukir Macan Kurung (Hariyadi, 2010). Pola penyusunan motifnya terpisah-pisah dalam bulatan-bulatan sehingga motif ini termasuk motif ceplok, maka nama motif kreasi baru ini diber judul Ceplok Ukir (Gambar 14). Motif ini menggambarkan kecintaan warga terhadap seni ukir dan sepak bola sebagai sesuatu yang kelihatannya terpisah jauh, namun di Jepara dapat menyatu dalam denyut nadi kehidupan di Jepara. Komposisi bentuk daun, tunas, bunga, dan buah yang 
terbingkai dalam bulatan bola mengisyaratkan doa-doa agar prestasi baik olah raga maupun kehidupan masyarakat senantiasa menjadi lebih baik di masa yang akan datang.

\section{Motif Ceplok Bal}

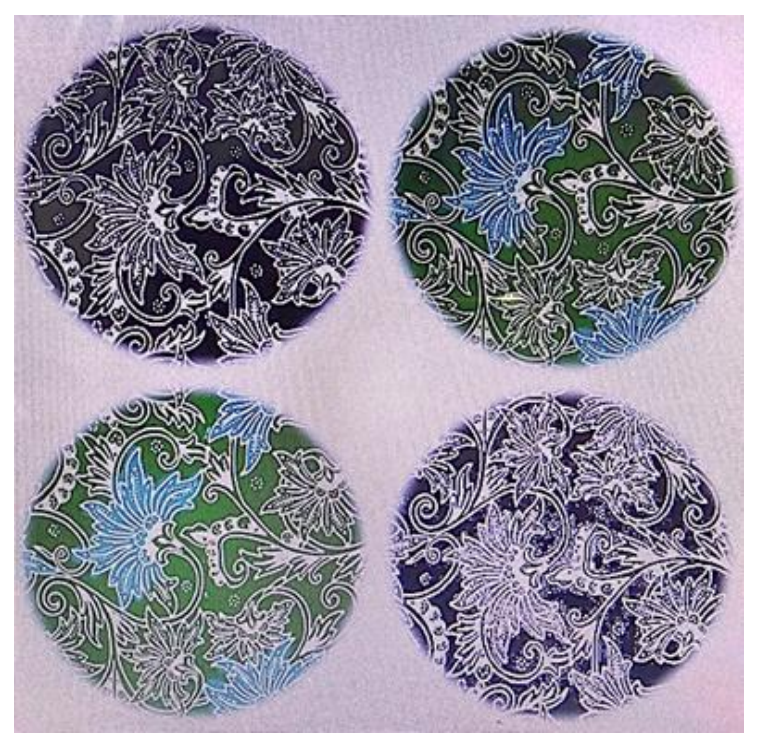

Gambar 15. Motif Ceplok Bal

Motif Ceplok Bal (Gambar 15) ini inspirasi dan proses kreatifnya sama dengan motif Ceplok Ukir (Gambar 14), namun menghasilkan motif lingkaran bulatan yang lebih besar dengan motif pengisi bentuk komposisi ukiran yang berbeda. Bal adalah bahasa Jawa yang berarti bola. Kecintaan yang besar terhadap olah raga bal-balan atau sepak bola warga Jepara tercermin dari banyaknya lapangan sepak bola (Hariyadi, 2010), klub-klub tingkat desa, sampai aktivitas anak-anak kampung bermain sepak bola dengan lapangan seadanya. Secara visual pola penyusunan motif ini terpisah-pisah dalam bulatan-bulatan yang lebih besar dengan bentuk motif ukir yang lebih kompleks, sehingga motif ini diberi judul Ceplok Bal (Gambar 15). Sama seperti motif Ceplok Ukir, motif Ceplok $\mathrm{Ba}$ / ini juga menggambarkan kecintaan warga terhadap seni ukir dan sepak bola sebagai sesuatu yang menyatu dalam denyut nadi keseharian masyarakat di semenajung pantai utara Jawa Tengah tersebut. Motif tradisional yang dikemas dalam corak kontemporer ini dihasratkan untuk doa pengharapan agar kehidupan masa depan senantiasa lebih baik (Eskak, 2016). Hasrat yang besar agar prestasi baik kesenian dan olah raga Jepara menjadi lebih berprestasi di masa depan.

\section{ASPEK KELAYAKAN DESAIN}

Pengembangan batik motif khas Jepara berarti melakukan penciptaan motif baru sebagai upaya diversifikasi desain sehingga dapat semakin memperkaya khasanah batik khas Jepara. Sesuatu kebaruan cenderung mengundang minat konsumen, sehingga desain baru dengan sendirinya akan mempunyai peminatnya (Sukaya, Eskak, \& Salma, 2018). Desain motif batik hasil dari penciptaan ini dibuat berdasarkan kreativitas seni dengan mempertimbangkan beberapa aspek berikut ini:

\section{Keunggulan Dibanding Desain Yang Sudah Ada}

Motif kreasi baru yang dikembangkan IKM batik Jepara umumnya hanya memindahkan gambar motif ukir material kayu ke motif batik material kain untuk sandang, sehingga motifnya terkesan berat dan kaku. Pengalihan motif dari ukir kayu ke kain batik memerlukan penyelarasan visual sehingga menghasilkan motif baru yang 
dapat dirasakan lebih luwes untuk penerapan pada kain (Salma \& Eskak, 2016). Keunggulan motif baru yang diciptakan dalam kegiatan ini adalah motif ukir kayu dikreasikan ulang agar menghasilkan motif yang sesuai untuk bahan sandang yaitu motif batik khas ukir namun secara visual terlihat lebih luwes. Keindahan pada produk akan meningkatkan nilai tambah serta merupakan daya tarik terhadap minat konsumen untuk membelinya (Eskak, Salma, \& Sumarto, 2017). Kreativitas IKM dengan menciptakan motif-motif baru yang lebih indah dan berciri khas seni budaya suatu daerah akan menimbulkan minat pecinta batik untuk membelinya (Salma \& Eskak, 2016).

\section{Aspek Kelayakan Ekonomi}

Kreasi motif baru juga turut menciptakan konsumen baru sehingga akan meningkatkan nilai penjualan produk. Nilai seni dan kebanggaan terhadap budaya yang tergambarkan pada motif batik khas daerah membuat konsumen rela membayar lebih mahal demi memiliki batik yang unik dan berbeda dari motif mainstream. Nilai keindahan atau estetika biasanya memberikan porsi lebih tinggi dari penentuan harga suatu produk seni rupa (Eskak, 2016b). Pengembangan yang dilakukan terus menerus berarti melakukan usaha peningkatan nilai penjualan yang terus menerus pula, sehingga IKM semakin untung dan semakin maju (Salma, Masiswo, Satria, \& Wibowo, 2015). Namun juga memerlukan bekal pengetahuan minat pasar, kondisi pasar, potensi pasar, dan strategi penjualan (Eskak \& Salma, 2017).
Uraian kualitatif tersebut di atas dapat menjadi gambaran bahwa usaha pengembangan motif-motif baru khas daerah mempunyai kelayakan ekonomi, tentunya diikuti dengan promosi yang gencar.

\section{Kelayakan Sosial dan Lingkungan}

Penciptaan batik motif khas Jepara dan penerapannya pada IKM berarti turut memajukan usaha meningkatkan kesejahteraan masyarakat. Berkembangnya kegiatan usaha batik turut membuka peluang majunya kegiatan sosial dan lingkungan setempat (Salma, Masiswo, Satria, \& Wibowo, 2015). Usaha kerajinan batik bersifat padat karya sehingga dapat menyerap tenaga kerja yang cukup banyak. Usaha dapat bersifat perusahaan maupun usaha rumahan. Teknologi pembuatan batik juga cukup mudah dipraktekkan baik untuk usaha menengah maupun kecil skala rumah tangga. Usaha kreatif seperti kerajinan batik ini seperti lokomotif industri yang semakin bergerak maju juga mampu menggerakkan usaha produktif bidang lainnya. Sebagaimana industri kreatif ukir dan mebel kayu Jepara mampu menjadi salah satu penggerak perekonomian daerah. Perlu juga kedepannya dikembangkan batik kayu, yaitu perpaduan teknik batik pada produk kerajinan kayu, sesuatu yang sangat memungkinkan terjadi di Jepara, seperti halnya terjadi di Krebet, Bantul, Yogyakarta (Sukaya, Eskak, \& Salma, 2018).

\section{ESTETIKA BATIK MOTIF UKIR JEPARA}

Ketika mengamati hasil karya motifmotif batik khas Jepara di atas, bisa 
menimbulkan kesan bahkan terpesona terhadap keindahan motif-motif yang ada. Rasa indah yang timbul adalah karena adanya nilai-nilai keindahan dalam suatu karya. Keindahan yang terkandung dalam motif batik tematik "motif ukir Jepara" ini terdapat pada harmonisasi dari penyusunan elemen-elemen motif yaitu motif pokok, motif pengisi, dan isian atau isen-isen. Motif terbentuk dari unsur-unsur rupa yaitu: garis, bidang, ruang, warna, dan tekstur, yang disusun harmonis sehingga mempunyai nilai estetika. Estetika adalah hal yang terkait dengan keindahan dan rasa (Susanto, 2011). Keindahan adalah nilai yang diberikan pada sesuatu yang dianggap mengandung unsur seni (Trianton, 2013). Sebuah karya terdiri dari unsur-unsur rupa yang ditata dengan penuh kesadaran dan kejiwaan, sebagai hasil transformasi gejolak jiwa yang kontemplatif dan optimal, dengan menggunakan pengetahuan kesenirupaan dalam upaya mengembangkan nilai estetikanya (Irawan \& Tamara, 2013). Keindahan terkonsepsi dengan memenuhi banyak aspek, salah satunya adalah aspek jasmani dan aspek rohani (Ralli \& Salma, 2013). Motif batik, sebagaimana karya seni rupa lainnya mengandung unsur-unsur rupa berupa garis, bentuk, bidang, warna, dan tekstur dalam suatu komposisi harmonis (Sanyoto, 2010). Batik motif ukir ini selain memiliki nilai keindahan juga memiliki nilai kegunaan, yaitu sebagai bahan sandang maupun untuk dekoratif interior. Nilai guna dari produk juga merupakan daya tarik tersendiri, karena konsumen tidak saja mendapatkan karya yang indah, namun juga karya yang dapat dimanfaatkan untuk kegunaan fisik dalam kehidupan sehari-hari. Berpadunya keindahan dan fungsi dapat semakin membangun tinggi nilai keindahan atau estetika (Sumardjo, 2000).

Batik sebagai karya seni adalah objek pengetahuan yang memiliki segala sesuatu yang berkaitan dengan masalah bentuk, fungsi, dan keindahan. Objek kajian dari estetika adalah masalah keindahan. Aristoteles (dalam Salma \& Eskak, 2012) merumuskan keindahan dalam kalimat "that which being good is also pleassant" artinya sesuatu yang selain baik juga menyenangkan. Tentang keindahan Read (1976) mengatakan "unity of formal relations among our sense perception" yang artinya kesatuan dari hubungan-hubungan bentuk di antara pencerapan-pencerapan indera kita. Jadi sesuatu dikatakan indah bila ada kesatuan bentuk dari unsurunsurnya yang bersifat harmonis. Sedangkan Santana (dalam Salma \& Eskak, 2012) menjelaskan tentang keindahan yaitu "beauty is pleasure regarded as the quality of a thing", artinya keindahan adalah kesenangan yang dianggap sebagai sifat dari suatu benda. Batik Ukir Jepara dibuat dengan menyusun unsur-unsur seni rupa (garis, bidang, warna, dan tekstur) secara harmonis agar menjadi desain yang indah, juga konsep karyanya dibuat dengan muatan nilai-nilai filosofis, sehingga karya batik tersebut mempunyai nilai estetika.

\section{UJI ESTETIKA MOTIF}

Motif-motif batik kreasi baru khas Jepara yang dihasilkan dalam kegiatan ini telah dilakukan penilaian estetika oleh ahli profesional praktisi maupun akademis. 
Tabel 1 menunjukkan hasil penilaian terhadap motif, rata-rata bernilai baik (B) atau motif dapat dikatakan indah dan sesuai diterapkan pada kain batik. Motif yang mendapat penilaian baik sekali (A) yaitu motif: Lung Merak, Ceplok Ukir, dan Ceplok Bal.

Tabel 1. Hasil penilaian estetika motif

\begin{tabular}{lll}
\hline No & \multicolumn{1}{c}{ Motif } & Nilai \\
\hline $\mathbf{1}$ & Lung Merak & A \\
$\mathbf{2}$ & Lung Ngrembaka & B \\
$\mathbf{3}$ & Lung Cinta Jepara & \\
$\mathbf{4}$ & Lung Wuni & B \\
$\mathbf{5}$ & Lung Gunung & B \\
$\mathbf{6}$ & Lung Lereng & B \\
$\mathbf{7}$ & Lung Ceplok Semi & C \\
$\mathbf{8}$ & Lung Poleng Ceplok & B \\
$\mathbf{9}$ & Ceplok Ukir & B \\
$\mathbf{1 0}$ & Ceplok Bal & A \\
\hline Keterangan: & A \\
A $=$ & Sangat Baik \\
B $=$ & Baik \\
C $=$ Cukup & \\
D $=$ & Kurang & \\
E $=$ Jelek &
\end{tabular}

\section{KESIMPULAN DAN SARAN}

\section{Kesimpulan}

Kegiatan membatik di Jepara sudah ada ketika zaman R.A. Kartini (1879-1904), namun tidak berkembang seperti industri lainnya, seperti: ukir kayu, perhiasan monel, maupun tenun Troso. Dewasa ini industri batik Jepara mulai tumbuh kembali. IKM batik Jepara telah melakukan penciptaan motif khas daerah dengan inspirasi dari seni ukir kayu, namun hasilnya masih terlihat kaku atau kurang sesuai sebagai motif hias untuk diterapkan pada kain. Peduli dengan kondisi yang ada, dilakukanlah penciptaan seni ini sebagai ikhtiar untuk menghasilkan motif batik yang lebih luwes sehingga sesuai untuk dekorasi pada kain. Metode penciptaannya yang digunakan telah memperlancar terciptanya 10 motif yaitu: Lung Merak, Lung Ngrembaka, Lung Cinta Jepara, Lung Wuni, Lung Gunung, Lung Lereng, Ceplok Semi, Ceplok Poleng, Ceplok Ukir, dan Ceplok Bal. Pada tahap akhir dilakukan penilaian estetika motif, dengan hasil nilai rata-rata baik (B). Motif yang mendapat penilaian baik sekali (A) yaitu motif: Lung Merak, Ceplok Ukir, dan Ceplok Bal. Dengan demikian secara estetika hasil karya motif telah mempunyai nilai keindahan.

\section{Saran}

Penciptaan motif batik ini dapat dikembangkan lebih lanjut dengan tema khas Jepara yang lebih beragam, namun masih mencerminkan karakteristik seni khas Jepara. Tulisan ini diharapkan dapat menginspirasi penciptaan-penciptaan kreatif berikutnya, kepada desainer batik, IKM batik, dan para pembaca yang budiman.

\section{KONTRIBUSI PENULIS}

Penulis pertama maupun penulis kedua merupakan kontributor utama dalam 
penulisan Motif Ukir Dalam Kreasi Batik Khas Jepara ini.

\section{UCAPAN TERIMA KASIH}

Terima kasih disampaikan kepada: ISI Yogyakarta, Dinas Perindag Kabupaten Jepara, IKM batik dan tenun Jepara, Balai Besar Kerajinan dan Batik, Edi Eskak, S.Sn, M.Sn, dan pihak-pihak yang telah banyak membantu dalam kegiatan ini.

\section{DAFTAR PUSTAKA}

BSN. (2014). SNI 0239. Batik - Pengertian dan Istilah. Jakarta: BSN. Indonesia.

Cemerlang, R. (2018). Master Atlas Terlengkap dan Terbaru Indonesia dan Dunia. Yogyakarta: C-Klik Media.

Eskak, E., \& Salma, I. R. (2018). Menggali Nilainilai Solidaritas Dalam Motif Batik Indonesia. Jantra, 13(2), 240-255.

Eskak, E., \& Salma, I. R. (2017). Minat Konsumen Terhadap Desain Produk Tas dari Limbah Ban Dalam di Yogyakarta. In Prosiding Seminar Nasional Kulit, Karet dan Plastik ke-6 (pp. 75-85). Balai Besar Kulit Karet dan Plastik.

Eskak, E. (2013). Krisis Bahan Baku Seni Kerajinan Kayu Di Jepara Dan Solusi Pemecahannya. Dinamika Kerajinan Dan Batik, 30(2), 73-84.

Eskak, E. (2013). Mendorong Kreativitas Dan Cinta Batik Pada Generasi Muda Kritik Seni Karya Pemenang Lomba Desain Batik Bbkb 2012. Dinamika Kerajinan Dan Batik, 30(1), 1-10.

Eskak, E. (2013). Rupa Karsa: Eksplrorasi Limbah Dalam Seni. Institut Seni Indonesia Yogyakarta.

Eskak, E. (2014). Metode Pembangkitan Ide Kreatif Dalam Penciptaan Seni. Corak, 2(2), 167-174.

Eskak, E. (2016a). Bambu Ater (Gigantochloa Atter) Sebagai Bahan Substitusi Kayu Pada Ukiran Asmat. Dinamika Kerajinan Dan Batik, 33(1), 55-66.

Eskak, E. (2016b). Identifikasi Pola Laminasi Tempurung Kelapa. Dinamika Kerajinan
Dan Batik, 32(2), 107-116.

Eskak, E. (2018). Wawancara Pengembangan Desain Motif Batik, December 17, 2018. Yogyakarta.

Eskak, E. \& Sumarno. (2016). Peningkatan Nilai Tambah Pada Cacat Batang Kayu Dengan Kreasi Seni. Dinamika Kerajinan Dan Batik, 33(2), 133-143.

Eskak, E., Sumarto, H. \& Salma, I. R.. (2017). Peningkatan Kecerahan Dan Daya Rekat Warna Pada Produk Gerabah Batik. Dinamika Kerajinan Dan Batik, 34(2), 125134.

Gustami, SP. (2000). Seni Kerajinan Furniture Ukir Jepara, Kajian Estetik Melalui Pendekatan Multidisiplin. Yogyakarta: Penerbit Kanisius.

Gustami, S. (2008). Nukilan Seni Ornamen Indonesia. Yogyakarta: Arindo Nusa Media.

Hariyadi, K. (2010). Macan Kurung Belakang Gunung. Jepara: Pemerintah Kabupaten Jepara.

Indriani, R., \& Rachmawati, D. (2016). Cantiknya Batik yang Mengadopsi Motif Ukiran Kayu ini. Retrieved September 27, 2018, from https://www.suara.com/lifestyle/2016/08/2 8/201025/cantiknya-batik-yangmengadopsi-motif-ukiran-kayu-ini

Irawan, I. dan Tamara, P. (2013). Dasar-dasar Desain Untuk Arsitektur, Interior, Seni Rupa, Desain Produk Industri dan Desain Komunikasi Visual. Jakarta: Griya Kreasi.

Kotak Perhiasan Ukir Kayu Jati Kartini Jepara. (2018). Retrieved September 26, 2018, from https://kriyaukir.com/kotakperhiasan-ukir-kayu-jati-kartini-jepara/

Marianto, M. D. (2017). Art and Life Force in a Quantum Perspektive. Yogyakarta: Scritto Book Publisher.

Ningrum, I. W. (2015). Bentuk Dan Makna Satuan Lingual Nama-Nama Motif Seni Ukir Jepara. Universitas Negeri Semarang.

Pratiwi, A. P., Kenang, K. K., \& Ruki, U. A. (2017). Analisa Perkembangan Motif Ukiran Di Jepara Pada Abad Ke-16 Hingga Abad Ke17. 2. Kreasi, 2(2), 5-25.

Ralli, V., dan Salma, I. R. (2013). Rupa Karsa: Eksplorasi Kayu Limbah Dalam Seni Kajian Estetika Pada Karya Edi Eskak, 30(2), 99108. 
Read, H. (1976). The Meaning of Art. New York: Preager.

Salma, I. R., \& Eskak, E. (2012). Kajian Estetika Desain Batik Khas Sleman Semarak Salak. Dinamika Kerajinan Dan Batik, 32(2), 1-8.

Salma, I. R., \& Eskak, E. (2016). Ukiran Kerawang Aceh Gayo Sebagai Inspirasi Penciptaan Motif Batik Khas Aceh Gayo. Dinamika Kerajinan Dan Batik, 33(2), 121-132.

Salma, I. R., Eskak, E., dan Wibowo, A. A. (2016). Kreasi Batik Kupang. Dinamika Kerajinan Dan Batik, 33(1), 45-54.

Salma, I. R., Masiswo., Satria, Y., dan Wibowo, A. A. (2015). Pengembangan Motif Batik Khas Bali. Dinamika Kerajinan Dan Batik, 32(1), 23-30.

Salma, I. R., Wibowo, A. A., \& Satria, Y. (2015). Kopi Dan Kakao Dalam Kreasi Motif Batik Khas Jember. Dinamika Kerajinan Dan Batik, 32(2), 63-72.

Sanyoto, S. E. (2010). Nirmana: Elemen-elemen Seni dan Desain. Yogyakarta: Jalasutra.

Soepratno. (2004). Ornamen Ukir Kayu Tradisional Jawa. Semarang: Effhar.

Sukaya, Y., Eskak, E., dan Salma, I. R. (2018). Penambahan Nilai Guna Pada Kreasi Baru Produk Boneka Batik Kayu Krebet Bantul. Dinamika Kerajinan Dan Batik, 35(1), 15-24.

Sulastin, S. (1985). Surat-surat Kartini: Renungan Tentang dan Untuk Bangsanya. Jakarta: Jambatan.
Sumardjo, J. (2000). Filsafat Seni. Bandung: Penerbut ITB.

Sunaryo, A. (2009). Ornamen Nusantara: Kajian Khusus Tentang Ornamen Indonesia. Semarang: Dahara Prize.

Sunaryo, A. (2018). Seni Rupa Nusantara: Pengantar Kajian dan Apresiasi Seni. Semarang: Dahara Prize.

Supriono, P. (2016). The Heritage Of Batik: Identitas Pemersatu Kebanggaan Bangsa. Yogyakarta: Penerbit Andi.

Susanto, M. (2011). Diksi Rupa. Yogyakarta: DictiArtLab.

Susanto, S. K. S. (2018). Seni Kerajinan Batik Indonesia. (T. A. BBKB, Ed.). Yogyakarta: ANDI.

Sutarya. (2014). EKSISTENSI BATIK JEPARA. Disprotek, 5(1), 19-33.

Trianton, T. (2013). Estetika Profetik Ahmad Tohari Dalam Khazanah Budaya Cablaka. Ibda', Jurnal Kebudayaan Islam, 11(2), 211226.

Yoga, W. B. S., \& Eskak, E. (2015). Ukiran Bali Dalam Kreasi Gitar Elektrik. Dinamika Kerajinan Dan Batik, 32(2), 117-126. 
IKh Dinamika Kerajinan dan Batik: Majalah Ilmiah. Vol. 36 No. 1, Juni 2019, Hal. 17-34 